\title{
Student Representation in Solving Story Problems Using Polya Steps
}

\author{
Mohammad Archi Maulyda ${ }^{1}$ (*), Sukoriyanto ${ }^{2}$, Vivi Rachmatul Hidayati ${ }^{3}$, \\ Muhammad Erfan ${ }^{4}$, Umar $^{5}$ \\ 1,3,4,5 FKIP, Universitas Mataram, JL. Sriwijaya/No.22, Seganteng Mataram, NTB, \\ Indonesia \\ ${ }^{2}$ FMIPA, Pendidikan Matematika, JL. Semarang/No.5, Malang, Jatim, Indonesia
}

Received: September 5, 2019

Revised: February 29, 2020

Accepted: March 02, 2020

\begin{abstract}
The purpose of this descriptive qualitative study is to look at the representation of students in solving problems about stories. Subjects were selected based on the results of pretest questions and short interviews conducted on 28 students in 1 class. Of the 28 students who were the subjects of the study, 2 students were chosen to represent 2 categories of answers that appeared in 1 class. Each category, namely the category of students who answered correctly and students who answered incorrectly, were randomly assigned to one student for further analysis. The research location was Malang Saladin Middle School. Subjects will be given test questions and will be interviewed to gather information regarding the results of their work. The results of this study indicate that there are still students who have difficulty in solving mathematical problems in the form of story problems. This research also shows that representation plays an important role in the success of students in solving story problems.
\end{abstract}

Keywords: Representation, Polya, Story Problems, Mathematics

(*) Corresponding Author: $\quad$ archimaulyda@ unram.ac.id \& 08154192370

How to Cite: Maulyda, M.A., Sukoriyanto, S., Hidayati, V.R., Erfan, M., \& Umar, U. (2018). Student representation in solving story problem s using Polya steps. Formatif: Jurnal Ilmiah Pendidikan MIPA, 10 (1): 25-34. http://dx.doi.org/10.30998/formatif.v10i1.4629

\section{INTRODUCTION}

Mathematics is a basic science that can support other sciences and is a means of scientific thinking that is expected to be well learned and mastered by students according to their level of education. The Center for Education states that mathematics is the science of logic regarding the form, composition, quantity, and concepts related to one another which is divided into three fields namely algebra, analysis, and geometry (Galen \& Eerde, 2013). Cristobal \& Lasaten (2018) claims that mathematics consists of components: (1) language, (2) statements, (3) questions, (4) reasons, and (5) ideas mathematics itself. Mathematics plays an important role in a learning process because a person will be trained to think critically, creatively, logically, analytically, and systematically (The National Council of Teachers of Mathematics, 2000).

As with mathematics, problem-solving is also important. The ability to solve a problem is very necessary for students to understand concepts, relationships between concepts, and relationships between concepts with other fields (Suhendri, 2015). According to Marliani (2015), problem-solving generally builds representations of problems to facilitate understanding. This is confirmed by the statement of Yuliyani, Handayani, \& Somawati (2017) that problem-solving is a basic skill needed by students 
today and problem solving is the main focus of the mathematics curriculum. In line with that NCTM (2000) states that problem-solving is the "heart" of mathematics. According to Polya (1957), the formulation of problem-solving steps can be done by (1) Understanding the Problem (understanding the problem), (2) Devising a Plan (compiling a plan), (3) Carry Out the Plan (carrying out the plan) and (4) Looking Back.

Although problem-solving is the "heart" of mathematics, there are still many students who have difficulty solving problems. Pourdavood, Mccarthy, \& Mccafferty (2015) in his research explained that students had difficulty in solving mathematical problems in the form of story problems. Difficulties experienced include understanding and making generalizations about mathematical skills and concepts, and mathematical concepts or procedures (Maulyda, Hidayanto, \& Rahardjo, 2019). A similar sentiment was also conveyed by Bertolin (2018) that students' difficulties in solving story problems include reading and understanding, reading all information, information that disturbs attention, imagining context, writing mathematical sentences, calculations and translate answers. This happens because students do not represent the information in the problem correctly (King, 2014). Because questions in the form of problems are more easily resolved if the students' representational abilities are good. Students are said to have been able to solve a problem if they can understand the problem, can plan the solution of the problem, and can do the calculation and check the results of calculations that have been done (Faradillah, 2018).

At the junior high school level, a lot of math material is in the form of story problems. Story questions are seen to improve students' ability to solve mathematical problems. This is because problems in the form of story problems will require students to make analogies between the problem and the strategy of solving or solving models. In making this analogy students must be able to understand the problem well. When understanding a problem students must have good representation skills (Pourdavood et al., 2015). This is because the ability of a person's representation will affect students' understanding of the given problem. When there is an error in understanding the problem given, the choice of strategy for the problem will also be wrong. As a result, the results obtained are also not right (Croft, Kouvela, \& Paul Hernandez-Martinez, 2018). Previous studies only looked at students' problem-solving processes (Problem-Solving). Even though in the step of understanding the problem (Understanding the Problem) one aspect that plays a role is the ability of student representation. If at this stage students make a mistake, then the error will continue until the calculation phase and get the conclusion of the answer (Purohit, 2016).

Looking at the facts that have been presented, it is important to explore how students' representations in solving problems with the story using Polya steps. This research was conducted in the hope that the teacher as an educator had a picture related to the process of student representation. By knowing where the errors that students are inclined to make, the teacher can provide appropriate actions to reduce those mistakes from happening again.

\section{METHOD}

This research is descriptive qualitative research which is one type of qualitative research. By the opinion of Creswell (2012), a qualitative approach is a research procedure that produces qualitative data, words or notes of the people themselves or their observed behavior. This type of research was chosen because the purpose of this study was to describe how the representation of students in solving mathematical problems in 
terms of Polya's steps. The research location is Malang Shalahudin Middle School. The subject selection technique in this study was purposive sampling. The subjects of this study were 28 students in class VIII-D. Researchers provide test questions to all students in the class.

Based on the results of student work, 11 students who answered right and 17 others were still wrong in answering test questions. Of the students who answered right and wrong, the researcher took each of the students for further analysis. This selection is carried out randomly because it sees similar student work, so the subject can represent the other subjects in each category. Furthermore, the two subjects will be further investigated for their representation. Both subjects were given the S1 code for the first subject and S2 for the second subject.

Two subjects will be given test questions. The procedure for solving student problems is adjusted to the steps of Polya. So before being given a test, the subject is first taught about problem-solving procedures that are following Polya's steps. After working on the test questions, the subject will be interviewed related to the results of his work. The interview is an unstructured interview intending to explore information related to the representation made by the subject in solving problems. Test results and interviews of the two subjects were then analyzed based on the indicator representations that had been made. The following indicators are formulated by researchers.

Table 1. Representation Indicators

\begin{tabular}{l|l|c}
\hline \multicolumn{1}{c|}{ Representation Indicators } & Operational Description & Code \\
\hline $\begin{array}{l}\text { Use Representation to Resolve } \\
\text { Problems }\end{array}$ & $\begin{array}{l}\text { Understand the problem } \\
\text { given }\end{array}$ & $\mathrm{R} 1$ \\
\hline & $\begin{array}{l}\text { Make a form of } \\
\text { representation to solve } \\
\text { problems }\end{array}$ & $\mathrm{R}$ \\
\hline
\end{tabular}

The results of the analysis of student work are then used as consideration in the conclusion of the study. Therefore, the data collection techniques used in this study are tests and interviews. The instrument used in this study was a description test. This problem is a modification of the VII-grade mathematics textbook K-13 curriculum. The following are questions given to students.

Uang saku kiki Rp. 2.000,00 lebih banyak dari uang saku adiknya. Setiap hari Ibunya memberi uang setinggi - tingginya Rp. 15.000,00. Buatlah model matematika dan tentukan berapa paling banyak uang saku yang diterima kiki dan adiknya!

\section{RESULTS \& DISCUSSION}

Following are the results of S1 and S2 work: 


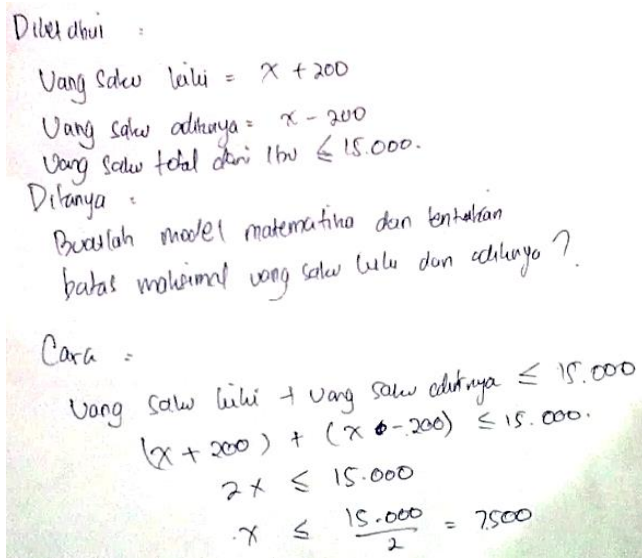

Figure 1. S1 Work Results

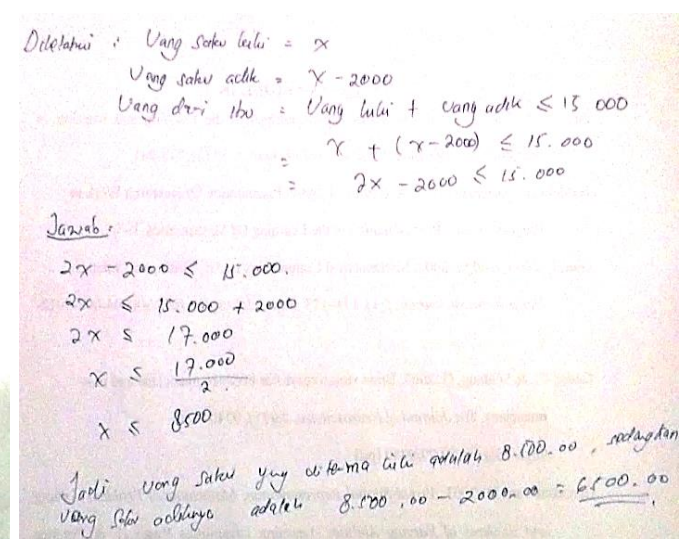

Figure 2. S2 Work Results

\section{Understanding the Problem}

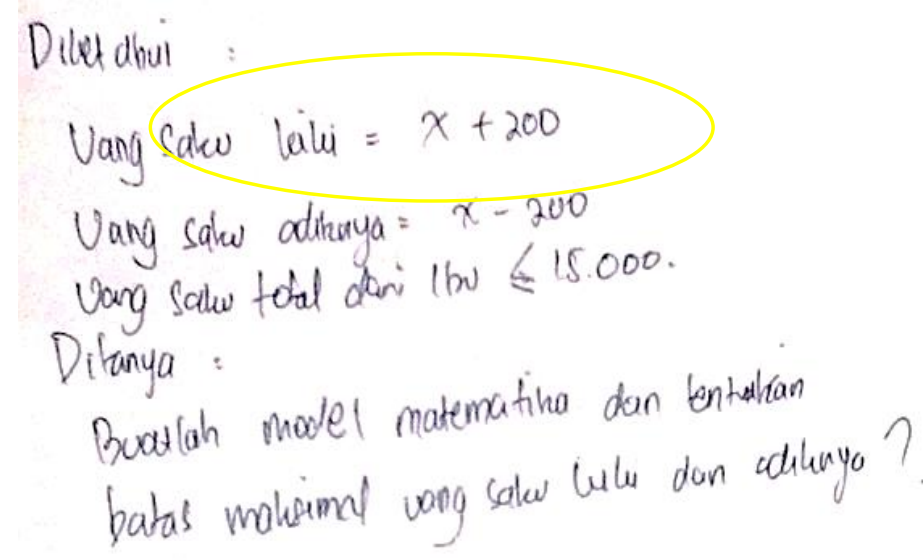

Figure 3. S1 Work Outcomes in understanding the problem

We can see in Figure 3, that S1 has made a mistake in understanding the problem. Seen in the yellow circle, S1 misrepresents the sentence in the question "Kiki pocket money Rp. 2,000.00 more than his sister's allowance ". Misrepresentation is also seen in the following interview results:

$\mathrm{P}$ : "What do you mean by pocket money equal to $\mathrm{x}+200$ "?

S1: "Kiki's pocket money is 200 times more than his sister's, I suppose $\mathrm{x}$ is pocket money, so it's $x+200$ sir, eh I mean 2000 sirs, less 0."

From the results of the interview, it can be seen that S1 made a mistake in understanding the questions. This error is due to an incorrect sentence representation from S1 regarding kiki's allowance. S1 considers that the word "more" means the total in the mathematical model, whereas the word "more" means that the allowance for kiki is more than 2,000 rupiah from kiki. As a result, S1 does not meet the indicator R1. Safi \& Desai (2017) explained that an external misrepresentation will result in incorrect information entry. Because the wrong representation of $\mathrm{S} 1$, resulting in the information obtained is also not right. So that an error occurs in understanding the problem. This is consistent with research conducted by Maulyda, Hidayati, Rosyidah, \& Nurmawanti (2019) which shows that the most frequent mistakes students make in solving problems are understanding the problem (understanding the problem). 


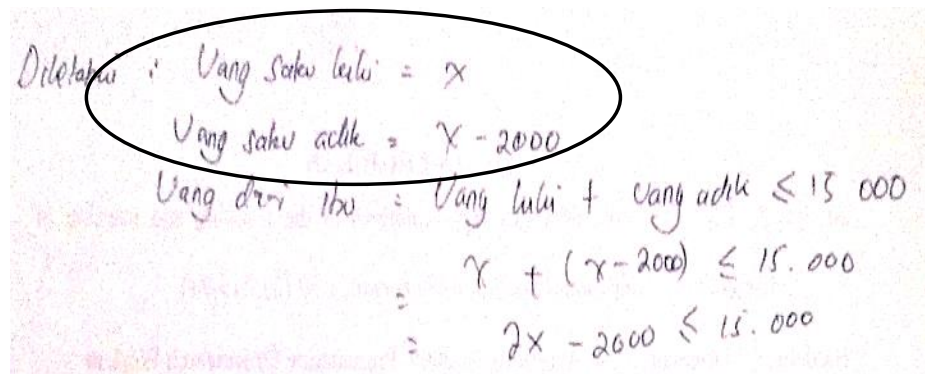

Figure 4. S2 Work Outcomes in understanding the problem

While on the results of S2 work, Figure 4 shows that $\mathrm{S} 2$ has been able to represent the problem sentences well. Seen in the black circle, S2 can identify information that is known in the problem to solve the problem. The following are the results of the interview with S2:

P: "Why is Kiki's allowance the same as $\mathrm{x}$ and her sister is the same as $\mathrm{x}-200$ "? S1: "Kiki's allowance is more than 2000, Sir, if I suppose Kiki's allowance with $\mathrm{x}$ means his sister's allowance is $\mathrm{x}-2000$. It means that Kiki's allowance is more than his brother's sir".

Based on the results of the interview, it can be concluded that $\mathrm{S} 2$ has understood the problem and fulfilled the indicator R1.

\section{Devising a Problem}

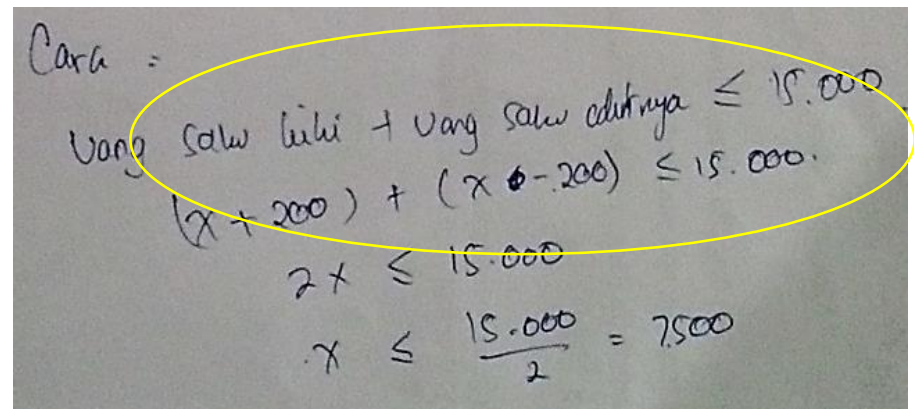

Figure 5. S1 Work Outcomes in Preparing a Plan

In Figure 5 it can be seen that $\mathrm{S} 1$ has made inequality for a good settlement plan. In the yellow circle, it is seen that $\mathrm{S} 1$ makes a mathematical model by representing the sentence "as high as possible" with the symbol " $\leq$ " which means the total amount of pocket money for kiki and his sister is not more than 15,000 rupiah. This contrasts with the results of research conducted by Hwang \& Chen (2007) who explained that many children at the junior high school level made mistakes when using the inequality symbol. But from the results of the work of S1, it turns out the subject can represent the symbol of inequality well. This can be seen in the following interview results:

P : "What does this mean?" (Showing a picture circled in yellow)

S1: "The maximum amount of money from Mother is 15,000 Sir, it means that Kiki's allowance plus the allowance of her sister is no more than 15,000".

$\mathrm{P}$ : "Then after that?"

S1: "Just enter what was already known sir, means $(x+2000)+(x-2000) "$. 
In the next step, because there is a wrong representation when understanding "pocket money" as a result the mathematical model created by $\mathrm{S} 1$ is also incorrect. Because what is known at the beginning of the kiki allowance is " $x+200$ " then S1 stimulates what is known into the equation created. Even though the equation is right because it is wrongly substituted, the mathematical model that was made is incorrect.

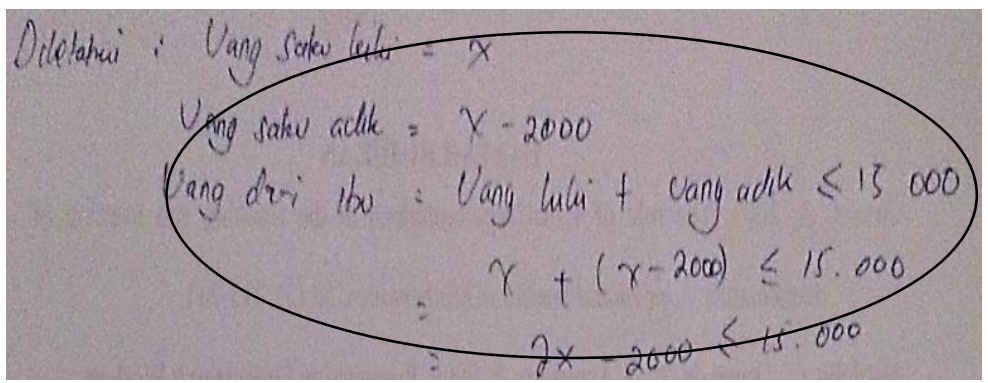

Figure 6. S2 Work Results in preparing plans

As for S2, the results of the work show that S2 can make the right settlement plan. Because the information obtained when understanding the problem is right, the mathematical model created is also right. Seen in the black circle in Figure 6, S2 makes a model to find the value of $\mathrm{x}$ with the $2 \mathrm{x}-2000 \leq 15,000$ inequality. The following are the results of the interview with $\mathrm{S} 2$ :

$\mathrm{P}:$ : Where did you get this inequality?" (Showing a picture circled in black

S2: "I added up the pocket money for Kiki and his brother, sir because I wanted to find the value of $x "$.

$\mathrm{P}$ : "Why look for the value of $\mathrm{x}$ ?"

S2: "In the beginning, I suppose Kiki's pocket money is the same as $\mathrm{x}$, to answer the question, I have to know the value of $\mathrm{x}$, sir".

From that interview, it can be concluded that $\mathrm{S} 2$ understands the plan that will be used to solve the problem. S2 sums up "kiki's allowance" and "her sister" to make an inequality that will be used to determine the value of $\mathrm{x}$.

\section{Carry Out the Plan}

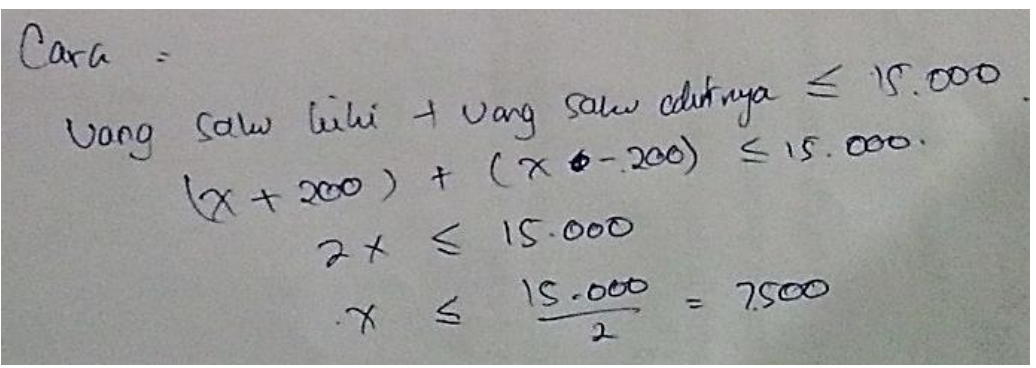

Figure 7. S1 Work Outcomes in Implementing the Plan

From Figure 7, it can be seen that $\mathrm{S} 1$ implements the plan by operating the inequality that was created earlier. But because of misrepresentation in understanding "pocket money" then the inequality is made wrong. Therefore when S1 looks for the value of $x$, the results obtained are wrong. From the picture circled in yellow, it can be seen that S1 wrote " $x \leq 15,000 / 2=7,500 "$. Researchers examined the intent of the writing through the following interview: 
P: "What does this mean?" (Pointing to the yellow circle on the work) students)

S1: "That means that $\mathrm{x}$ is smaller or equal to 7,500 sir".

P: "What does that mean?"

S1: "Yes, that means Kiki pocket money is at most 7,500 sir".

From this, we can see that the operation performed $\mathrm{S} 1$ in determining the $\mathrm{x}$ value is correct. However, because of the wrong representation made at the beginning, the final results obtained are not right. This is following the opinion of Maccini \& Gagnon (2017) who explained that mistakes that are often made by children when solving problems of equality or inequality, in addition to algebraic calculations, also on understanding the meaning of sentences under the equations and inequalities that are made also still frequently occur errors. Seen in the results obtained by S1, that algebraic operations carried out by $\mathrm{S} 1$ are correct, but as a result of misrepresentation that is done when the step of understanding the problem, the results obtained are also wrong. So it is said S1 does not meet the indicator R2.

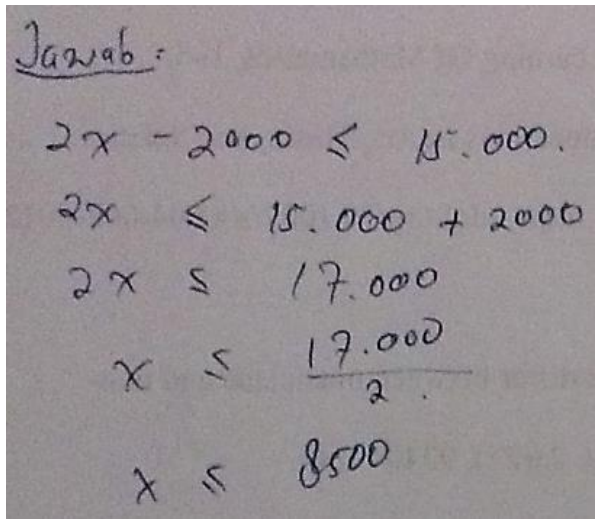

Figure 8. S2 Work Results in implementing the reorganization

On the results of S2 work, shown in Figure 8, it can be seen that S2 can carry out the completion plan well. Seen in the results of operations performed $S 2$, the value of $x$ obtained is correct, which is 8,500 rupiah. Using the previously created model S2 successfully determines the $\mathrm{x}$ value precisely. So $\mathrm{S} 2$ is said to meet the indicator R2.

\section{Looking Back}

The results of S1's work have stopped after finding the value of $\mathrm{x}$ because $\mathrm{S} 1$ considers that what is asked about the problem is to make a mathematical model and find out what the maximum allowance that Kiki might receive. Even though at the stage of understanding the problem, S1 had written that what was asked about the problem was "the maximum limit for Kiki and his younger brother's allowance". This is shown in the following picture: 


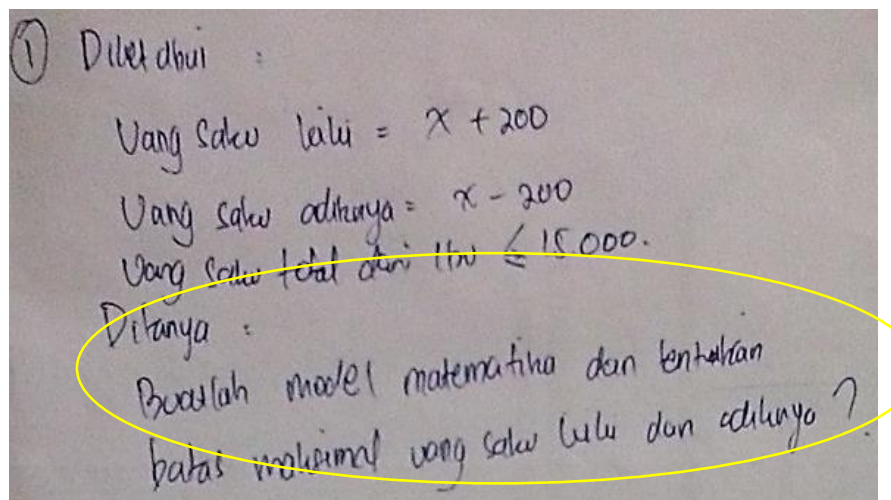

Figure 9. S1 Work Results in checking again

In Figure 9, it appears that $\mathrm{S} 1$ has correctly understood the information about what was asked in the problem. But when solving problems, S1 does not look for how much "sister's pocket money". This was confirmed by the following interview results:

P : "You're only looking for x value?"

S1: "Yes Sir, I forget that when asked for his sister's allowance as well".

$\mathrm{P}$ : "How can you forget?"

S1: "The problem is that I immediately collected Sir when I finished, I wanted to go to the canteen".

Looking at the results of the interview it can be seen that the S1 does not re-check the answers. Therefore the answers given do not match what was asked. This is in accordance with the opinion of Sztajn, Holt, Wilson, \& Webb (2016) which states the importance of carrying out checks in operations or strategies when solving mathematical problems. Because S1 does not check the results of its work, S1 makes mistakes when solving problems.

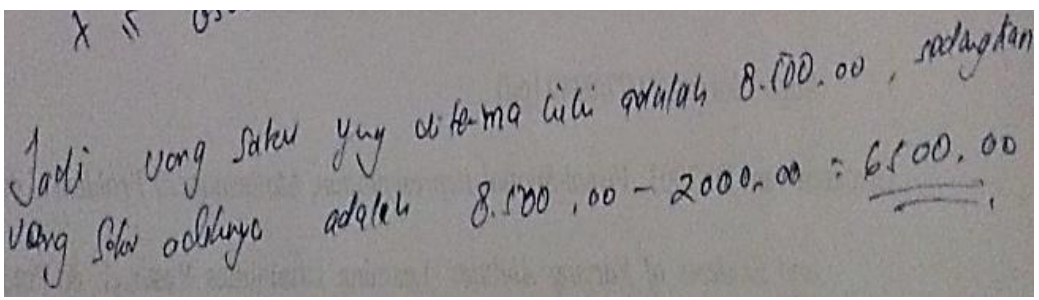

Figure 10. S2 Work Results in checking again

In the results shown in Figure 10, S2 has resolved the problem well. S2 can determine exactly how much pocket money Kiki and her sister received.

\section{CONCLUSION}

Based on the search results on the work of S1 and S2, it was concluded that: (1) there are still students who find it difficult to solve problems in the form of story questions, as evidenced by the discussion of S1 which shows that S1 cannot solve problems correctly; (2) the ability of representation plays an important role in solving problems of story problems, this is because story problems contain many sentences that must be accurately represented and following the resolution strategy. When there is an error in interpreting the sentence in the problem, then starting from the settlement strategy 
to the results will also be wrong, this is also seen in the S1 discussion, because of the misrepresentation made at the beginning, then the final result obtained also becomes wrong; (3) there are still students who cannot write mathematical sentences correctly, such as "unit", "amount", "rupiah", and so on, this is seen both in the work results of S1 and $\mathrm{S} 2$, thus it can be said that the representation made by students still not perfect.

\section{CONFLICT OF INTEREST}

Solving ability is currently a very important issue among education practitioners. From basic education to tertiary level, students' problem-solving abilities are trying to be improved. Reflecting on the results of PISA 2018 the results of which could not be accessed in 2019, Indonesia is in the top 10 positions for the quality of education. This is suspected because the questions tested in the PISA assessment require good problemsolving skills to be solved. Therefore, research related to students' problem-solving abilities becomes interesting to study.

\section{ACKNOWLEDGEMENT}

The researcher expresses gratitude to the Almighty God who has given grace for the completion of this article. The author also thanks all those who have contributed to the research. And we send our thankfulness to the school for giving permission of doing research.

\section{REFERENCES}

Bertolin, J. (2018). Higher education and development in the knowledge society. Higher Education for the Future, 5(2), 122-141. https://doi.org/10.1177/2347631118767279

Creswell, J. W. (2012). Educational research: Planning, conducting, and evaluating quantitative and qualitative research (4th ed.) (4th ed.). Boston, MA: Pearson.

Cristobal, J. A., \& Lasaten, R. C. S. (2018). Oral communication apprehensions and academic performance of grade 7 students. Asia Pacific Journal of Multidisciplinary Research, 6(3), 5-16. Retrieved from https://www.mendeley.com/catalogue/oralcommunication-apprehensions-academic-performance-grade-7-

students/\%0Awww.apjmr.com

Croft, T., Kouvela, E., \& Paul Hernandez-Martinez. (2018). This is what you need to be learning: an analysis of messages received by first-year mathematics students during their transition to university. Math Ed Res J, 30(1), 165-183.

Faradillah, A. (2018). Analysis of mathematical reasoning ability of pre-service mathematics teachers in solving algebra problem based on reflective and impulsive cognitive style. Formatif: Jurnal Ilmiah Pendidikan MIPA, 8(2). https://doi.org/10.30998/formatif.v8i2.2333

Galen, F. Van, \& Eerde, D. Van. (2013). Solving problems with the percentage bar. Journal on Mathematics Education, 4(1), 1-8. https://doi.org/10.22342/jme.4.1.558.1-8

Hwang, W., \& Chen, N. (2007). Multiple representation skills and creativity effects on mathematical problem solving using a multimedia whiteboard system Jian-Jie Dung 
Yi-Lun Yang. Educational Technology \& Society, 10(2), 191-212.

King, A. (2014). Mathematical explorations: Freshwater scarcity a proportional representation. NCTM, 20(3), 152-157.

Maccini, P., \& Gagnon, J. C. (2017). Perceptions and application of NCTM standards by special and general education teachers. Exceptional Children, 68(3), 325-344. https://doi.org/10.1177/001440290206800303

Marliani, N. (2015). Kemampuan pemecahan masalah matematis pada mata kuliah persamaan diferensial dilihat dari pembelajaran konflik kognitif yang terintegrasi dengan soft skill. Formatif: Jurnal Ilmiah Pendidikan MIPA, 5(2). https://doi.org/10.30998/formatif.v5i2.333

Maulyda, M. A., Hidayanto, E., \& Rahardjo, S. (2019). Representation of trigonometry graph funcsion colage students using GeoGebra. International Journal of Trends in Mathematics Education Research, 2(4), 193-196.

Maulyda, M. A., Hidayati, V. R., Rosyidah, A. N. K., \& Nurmawanti, I. (2019). Problemsolving ability of primary school teachers based on Polya's method in Mataram City. PYTHAGORAS: Jurnal Pendidikan Matematika, 14(2), 139-149.

Pourdavood, B. R., Mccarthy, K., \& Mccafferty, T. (2015). The impact of mental computation on children's mathematical communication, problem solving, reasoning, and algebraic thinking. Journal of Mathematical Analysis and Applications, 34(2), 1-13.

Purohit, K. C. (2016). Mathematics: Science of Pattern, Shapes and Number (1st ed.). New York: Springer.

Safi, F., \& Desai, S. (2017). Promoting Mathematical Connections Using ThreeDimensional Manipulatives. NCTM, 22(8), 101-111.

Suhendri, H. (2015). Pengaruh metode pembelajaran problem solving terhadap hasil belajar matematika ditinjau dari kemandirian belajar. Formatif: Jurnal Ilmiah Pendidikan MIPA, 3(2), 67-76. https://doi.org/10.30998/formatif.v3i2.117

Sztajn, C., Holt, E., WilsonPaola, \& Webb, J. (2016). Translating Learning Trajectories Into Useable Tools for Teachers. NCTM, 5(1), 219-230.

The National Council of Teachers of Mathematics. (2000). Principles and Standards for School Mathematics. Reston, VA: The National Council of Teachers of Mathematics, Inc.

Yuliyani, R., Handayani, S. D., \& Somawati, S. (2017). Peran efikasi diri (self-efficacy) dan kemampuan berpikir positif terhadap kemampuan pemecahan masalah matematika. Formatif: Jurnal Ilmiah Pendidikan MIPA, $7(2)$. https://doi.org/10.30998/formatif.v7i2.2228 